\title{
Why quasi-persons are not patentable
}

Sir - You report that the US patent office has rejected a bid by Stuart Newman and Jeremy Rifkin to patent techniques for creating a human-animal hybrid (Nature $399,626 ; 1999)$. In rejecting their claim, the examiner informed the would-be inventors that the US Patent Act does not cover the patenting of humans. Although the examiner is correct that property rights in a human cannot be granted under US law, the Newman-Rifkin invention raises a different question, as only a part of it is human. But even something that is only part human - a quasi-person — cannot be patented, according to constitutional law.

To be granted a patent in the United States, an invention must be new, useful and not obvious to a person skilled in the pertinent scientific discipline. In 1976, Chakrabarty tried to patent a bacterium genetically engineered to digest oil but, although the bug satisfied all three criteria, the patent office refused to grant a patent on the grounds that living organisms could not be patented. The Supreme Court overturned this decision, concluding that "Anything man-made under the sun can be patented".

That opened the door for patents on engineered, living organisms. Did it make humans patentable? A human being is 'man-made' (woman-made, too, of course) so it satisfies the first level of inquiry set out by the Supreme Court. A human is also new (the combination of genes is novel), useful, and not obvious (no one could predict what maternal and paternal genes would come together nor the resulting phenotype). All the criteria to earn a patent are met.

But the matter is not settled so simply. Patented inventions become the personal property of the inventors to dispose of as they see fit. However, under US law, a human cannot be held as property. The thirteenth amendment to the constitution, which ended slavery, prohibits taking property rights in human beings. A human, therefore, cannot be patented.

What about the patentability of hybrids? Rifkin suggests that the answer requires the patent office to define the maximum quantity of humanness that can be present in an organism for it to be considered patentable. But this analysis has already been done. Not only does the thirteenth amendment prohibit the ownership of a person, but it also forbids property rights in a quasi-person. When the constitution was framed in 1787, it contained a provision that slaves were to be counted as three-fifths of a person for the purpose of apportioning representatives to the Congress. The goal of the amendment was to outlaw slavery - to bar the ownership of Black people. But it did not change the legal status of Black people. They remained part-people (quasi-people) who were not entitled to vote, citizenship, or other rights. It was not until the fourteenth amendment was passed that Black people were made citizens and granted full personhood under the constitution.

The thirteenth amendment stood for the proposition that a quasi-person was not property to be held by another. So the patent office is correct in refusing to grant a patent on an organism that is only part human.

\section{Richard M. Lebovitz}

Evogen, 3515 Washington Blvd, No. 317, Arlington, Virginia 22201, USA

\section{Where a little aid could go a long way}

Sir - I support all the matters raised in the Commentary by Hin and Subramaniam, "Scientific societies build better nations" (Nature 399, 633; 1999). The suggestion that aid agencies should provide money to support scientific societies in developing countries, and to create federations of societies, strikes a chord. Even the production of a newsletter in Africa costs money that is not easily raised.

I am concerned with the development of biochemistry in Eastern Europe and Africa, and participated in the launch of the Federation of African Societies of Biochemistry and Molecular Biology. Many of the problems are similar in these different regions. The authors say that the creation of societies depends on the "coming together of scientists committed to translating a vision into reality". This is true but too often such people are inhibited because there is a bad relationship between the government and the universities. In these circumstances it takes a brave person to found a society that may later ask the government to increase funds for science. Such people tend to be regarded as troublemakers.

Effective aid should involve a partnership between the aid agency and the government but too often they act

independently. In the absence of an indication that the government takes science seriously, aid to individuals will often merely encourage a brain drain. Peter Campbell

University College London, London WC1E 6BT, UK

\section{More evidence needed}

\section{on effect of ivory ban}

Sir - Payne et al. express concern at the resumption of a limited trade in elephant ivory from Namibia, Zimbabwe and Botswana to Japan, and at the system for monitoring the illegal killing of elephants (MIKE) that supports the decision by the Convention on International Trade in Endangered Species (CITES) to allow this trade (Nature 399, 297; 1999). The authors correctly identify difficulties in devising survey methods, and of relating changes in populations to underlying causes. They are also disturbed that this decision may lead to proposals for future sales. But they misrepresent or misunderstand key points.

CITES did not decide to resume a limited ivory trade. Before the 1989 ban there had been a rampant ivory trade from illegally killed elephants. CITES decided to allow a one-off limited trade this year in stockpiled ivory under tightly controlled conditions, and to monitor the impact of this trade as an 'experiment'. Now that the sales have taken place, no further legal trade is allowed.

The 1989 ban should also have been regarded as an experiment, and monitored. When CITES meetings in 1992 and 1994 questioned whether the ivory ban was working effectively, no monitoring system was in place to provide an informed response. MIKE aims to fill a major gap by providing the best possible objective information for decision-makers.

The MIKE system was designed by IUCN, the World Conservation Union, as required by CITES. Experts were brought together from Africa and Asia, and their proposed system was passed through IUCN's elephant specialist groups for refinement, before approval by the CITES standing committee. What further peer review would Payne et al. desire?

An objective assessment of the one-off sale is not yet available. Nor has it been possible to assess the impact of the ban in any meaningful quantitative way. Yet Payne et al. assume that a total ban is the safest option for elephants, despite the numbers killed illegally since 1989 . MIKE has been designed to inform debate on such issues. If there is insufficient understanding to make decisions about limited trade, the same applies to decisions about a continued ban. Nigel Leader-Williams

Durrell Institute of Conservation and Ecology, Department of Anthropology, University of Kent at Canterbury, Canterbury CT2 7NS, UK 